Friedel Dubslaff

\title{
Genoptagelse ved hjælp af proformer ved simultantolkning fra tysk
}

Formålet med afhandlingen er, på basis af en empirisk undersøgelse, at belyse, hvordan pronominal og anden form for genoptagelse anvendes i tekster, som fremkommer ved simultantolkning fra tysk til et sprog, der - som dansk - er topologisk forskelligt fra tysk.

\section{Introduktion}

Baggrunden for det valgte emne er det kendte fænomen, at tolken pga. den tyske ordstilling undertiden må vente længe, inden ytringens mening afklares. For ikke at overbelaste hukommelsen vil han derfor tit vælge at starte med gengivelsen på målsproget, før han har hørt den udgangssproglige ytring i sin helhed. Når tolken på denne måde starter med at producere brudstykker, vil der i særlig høj grad være brug for, at han skaber eksplicit kohærens i målteksten. Dette ventes at ske vhja. pronominal genoptagelse, som traditionelt betragtes som et af de mest fremtrædende midler til at kæde teksters enkeltbestanddele sammen med og skabe tekstualitet (se for eksempel Halliday/Hasan 1976).

\section{Undersøgelsens forudsætninger og data}

De karakteristiske tyske rammekonstruktioner - verbal- og ledsætningsrammer (Helbig/Buscha 1993) - udgør et potentielt problem, når der skal tolkes til dansk, hvis topologiske regler kræver, at det finite verballed og eventuelle infinite verballed placeres langt tidligere i sætningen end i tyske sætninger (Lauridsen/Poulsen 1995). Også stærkt udvidede nominalrammer stiller lignende krav til tolkens hukommelse. Det, der forbinder alle tre typer af rammedannelser, er opbygningen af en spændingsbue mellem det rammeåbnende og det rammelukkende element.

Ud fra den nævnte formodning om, at tolken tit vil vælge ikke at vente på det rammelukkende element, opstilles den hypotese, at der ved simultantolkning fra tysk til et topologisk asymmetrisk sprog som dansk kan ventes forholdsvis mange forekomster af genoptagelser vhja. såkaldte proformer i målteksterne.

Det er en central antagelse i undersøgelsen, at proformer, som defineret af de Beaugrande/Dressler (1981), er specielt nyttige for tolken, fordi de kan bruges til at genoptage udtryk af betydeligt omfang fra den umiddelbart forudgående kontekst i kort form. Undersøgelsens genstand er ud over egentlige 
proformer som personlige og demonstrative pronominer og lokale adverbier også forskellige kombinationer med demonstrative pronominer, som normalt ikke betragtes som proformer (jfr. Koeppel 1993), men som har samme funktion i simultantolkeprocessen og derfor kaldes proformer i undersøgelsen, fx alle disse ting.

For at kunne afprøve hypotesen undersøges udelukkende proformer, som er redundante i forhold til udgangsteksten, dvs. kun dem, der ikke har et ækvivalent i udgangsteksten, og desuden udelukkes alle proformer, som kræves af det målsproglige system.

Det undersøgte målsproglige korpus består af 8 informanters tolkninger til dansk af 7 tyske taler af gennemsnitligt 5-6 minutters varighed. Talerne var oprindeligt blevet holdt i Europa-Parlamentet af 7 forskellige delegerede, men blev fremført af mig selv for den første informantgruppe (4 studerende ved Center for Konferencetolkning i København), mens den anden informantgruppe (4 professionelle tolke ved Europa-Parlamentet) tolkede de samme taler fra det bånd, der var blevet optaget under forsøgets første del.

\section{Undersøgelsens teoretiske rammer}

Beskrivelsen af unders $\varnothing$ gelsens teoretiske rammer starter med en redegørelse for begrebet genoptagelse. Forholdet mellem det udtryk, der bruges til genoptagelse, og det udtryk, der genoptages, opfattes som en kohærensrelation i overensstemmelse med den tekstlingvistiske forskning. De Beaugrande/ Dresslers (1981) diskursmodel bruges til at redegøre for proformernes rolle under opbygningen af et semantisk netværk. Desuden inddrages Ariels (1990) Accessibility Theory for en psykolingvistisk synsvinkel på proformer. Med Ariel betragtes proformerne som markører for en referents status i brugerens hukommelse: for eksempel indicerer personlige pronominer høj tilgængelighedsgrad, demonstrative derimod mellemhøj tilgængelighedsgrad. Endelig præsenteres Giles (1995) "Effort Model for Simultaneous Interpretation". Modellen tager udgangspunkt i tolkens begrænsede processeringskapacitet og er derfor velegnet som forklaringsmodel, når der, som i den her beskrevne opgave, opstår processeringsvanskeligheder pga. topologiske forskelle mellem udgangs- og målsprog.

\section{Genoptagelsessegmenternes funktioner i processen}

I alt blev der fundet 324 forekomster af ækvivalentløse anaforiske proformer i det målsproglige korpus. Disse proformer eller de genoptagelsessegmenter, som de indgår $\mathrm{i}$, blev inddelt i funktionskategorier. 


\subsection{Funktionstyper}

Der blev skelnet mellem primærfunktioner og øvrige funktioner. Genoptagelsessegmenter, som er karakteristiske for simultantolkeprocessen, betragtes som hørende til kategorien primærfunktioner ( 256 forekomster). De resterende 68 forekomster kunne ikke henføres til nogen primærfunktion, men relateres til det mundtlige medium generelt (35 forekomster), optræder som yderligere medspiller i et allerede registreret genoptagelsessegment med primærfunktion (19 forekomster) eller betragtes som tvivlstilfælde (14 forekomster, som lige så godt kunne blive anvendt i en oversættelsessituation). Disse ikke-specifikke forekomster blev ikke inddraget i hovedundersøgelsen.

\subsection{Primærfunktioner}

Kategoriseringen af genoptagelsessegmenternes typiske funktioner i simultantolkeprocessen blev foretaget på grundlag af tre typer data:

- de transkriberede måltekster

- udgangsteksterne (specielt med henblik på sætningernes syntaktisktopologiske beskaffenhed)

- båndmaterialets temporale informationer (specielt afstanden mellem taler og tolkene samt arten af pauser i input og output).

Der blev opstillet 7 primære funktionskategorier. Hovedundersøgelsens 256 genoptagelsessegmenter fordeler sig på disse 7 primærfunktioner som følger:

Rettelse

Opsamling

Supplering

Camouflering af usikkerhed el. informationstab

Rytmisk optimering

Forhaling

Rutineparafrase
$32 \%$

$22 \%$

$21 \%$

$10 \%$

$6 \%$

$5 \%$

$4 \%$

Som redskab til beskrivelsen af kategoriseringskriterierne bruges en simpel inddeling af de målsproglige ytringer i ytringsdel a og b, hvor del a indeholder eller udgør antecedenten, som genoptages i del b ved hjælp af proformen.

Ved rettelse tjener del b til at korrigere del a helt eller delvis. Det sker for det meste som følge af en prognosefejl i forbindelse med anticipation, når informanterne valgte ikke at vente på et rammelukkende element i udgangsteksten.

Primærfunktionen opsamling forekommer i flere varianter. Det er karakteristisk for de fleste opsamlingssegmenter, at de genoptager forskellige typer af syntaktisk ikke-integrerede sekvenser. Genoptagelsen kan da tjene til en for- 
holdsvis enkel temamarkering gennem en slags forfeltfordobling, men også til en strukturerende opsamling af uoverskuelige ytringsdele. Der forekommer dog også syntaktisk "korrekte" opsamlingsvarianter (opsamling efter opremsninger og forklarende opsamling af typen og det betyder at... ).

Genoptagelsen blev kategoriseret som supplering, når informanterne starter med at gengive delinformation fra en endnu ikke afsluttet kompleks helhed for ikke at skulle lagre for megen information i hukommelsen. Delinformationen præsenteres i form af en komplet prædikation, som genoptages og suppleres med den resterende information i del b, ligeledes i form af en komplet prædikation. I nogle få tilfælde har genoptagelsen det formål at supplere del a med et informationselement, som falder sent i den tyske sætning, uden at der er tale om det lukkende element i en rammekonstruktion. Dvs. at tolken ved afslutningen af del a endnu ikke havde modtaget det pågældende element og heller ikke forventede at skulle modtage yderligere information.

Genoptagelsessegmentet kategoriseres som (et forsøg på) camouflering af usikkerhed/informationstab, når del b blot er en parafraserende gentagelse af del a og står i stedet for udgangssproglige informationselementer, som mangler i tolkens gengivelse.

Rytmisk optimering antages at være genoptagelsessegmentets primærfunktion, hvis del b tjener til at undgå længere outputpauser, som ellers ville opstå som følge af pauser i input. Desuden anvendes del b i nogle få tilfælde til at udligne syntaktisk-topologisk ubalance i en målsproglig ytring.

Genoptagelsessegmentet antages at tjene til forhaling, når informanterne venter på et rammelukkende element $\mathrm{i}$ input og producerer floskelagtige vendinger på målsproget (eksempelvis af typen ... og det er en $x$, som ...), mens de venter.

Endelig anvendes genoptagelsessegmentet til at danne rutineparafraser med. Denne funktion antages at være den primære, hvis del a plus b tilsammen kan afkorte søgningen efter et adækvat leksem gennem parafrasering med simpelt leksikalsk materiale.

Da genoptagelsessegmenter kan bruges til flere funktioner samtidig, kan der forekomme overlapninger funktionerne imellem. Det var samspillet mellem de ovenfor anførte tre data-typer, der var afgørende ved kategoriseringen i de enkelte tilfælde.

\section{Undersøgelsens resultater}

\subsection{Fremlæggelse}

Undersøgelsens væsentligste resultat er, at det støtter den opstillede hypotese om sammenhæng mellem overtallige forekomster af genoptagelse og udgangs- 
sproglige rammekonstruktioner. Unders $\emptyset$ gelsen viser, at $83 \%$ af genoptagelsessegmenterne med primærfunktioner er affødt af potentielt problematiske udgangssproglige strukturer. De $68 \%$ forekommer ved tolkningen af ytringsenheder med rammekonstruktioner, som opfylder et nærmere fastsat mindstekrav til afstand mellem hhv. rammeåbnende og rammelukkende element, og de støtter derved hypotesen direkte. 15\% forekommer ved tolkning af strukturer, der ikke er specifikke for tysk som udgangssprog, men som har en sammenlignelig effekt i tolkeprocessen og som derved støtter hypotesen indirekte. Det drejer sig om ikke-kontinuerlige strukturer på den ene side (hypotaktiske og parentetiske strukturer) og komplekse strukturer, som indeholder megen information per tidsenhed, på den anden side (opremsninger og nominaliseringer). Yderligere 8\% overtallige proformer anvendes ved forskellige processeringsvanskeligheder uden fælles nævner. Kun de resterende $9 \%$ bruges overvejende ved ikke-problematiske konstellationer, nemlig i de to primærfunktioner rytmisk optimering og dannelse af rutineparafraser, som a priori er uafhængige af rammekonstruktioner.

På denne baggrund kan man tale om en genoptagelsesteknik, som bruges ved forskellige processeringsvanskeligheder.

Der blev ikke fundet et entydigt svar på spørgsmålet, om genoptagelse anvendes forskelligt af hhv. professionelle tolke og studerende. Ganske vist bruges genoptagelse i samme omfang af de to grupper, men inden for grupperne er der stor forskel i anvendelseshyppigheden.

Der blev heller ikke fundet tegn på, at tolkeretningen skulle have påvirket brugen af genoptagelse, for to af informanterne, som tolkede fra modersmålet til dansk, bruger genoptagelsen på samme måde som de øvrige informanter.

\subsection{Perspektivering}

Genoptagelsesteknikken belyses yderligere gennem diskussion af tre forskellige indfaldsvinkler, som formodes at have påvirket informanternes brug af genoptagelse.

På basis af Ariels Accessibility Theory diskuteres spørgsmålet, om tilgængelighedsmarkeringen i det målsproglige korpus skulle adskille sig fra de almindelige markeringsregler. En delkorpus-analyse viser, at dette ikke er tilfældet. Ganske vist er der en forholdsvis stor andel af mere specifikke proformer som disse ting, altså markører for mellemhøj tilgængelighedsgrad, taget i betragtning, at de forekommer inden for samme ytringsenhed og desuden ikke er frekvente i spontant talesprog. Men der er alligevel god grund til at bruge disse proformer, da informanterne foretrækker parataktisk frem for hypotaktisk strukturering og dermed en lavere grad af konnektivitet mellem (del)sætningerne. 
I en ekskurs om talesproget som indflydelsesfaktor påvises væsentlige ligheder mellem tolkesyntaks og talesprogssyntaks med hensyn til "fragmentering" (Chafe 1982), dvs. fordeling af information på flere selvstændige prædikationer. Denne informationsstruktur antages at lette produktionsfasen for tolken.

Kapitel 4 afsluttes med en gennemgang af litteraturen om simultantolkestrategier. Genoptagelse som produktionsstrategi nævnes ikke eksplicit i litteraturen, selv om fænomenet tit kan findes implicit i det anførte eksempelmateriale. Det konkluderes, at genoptagelse hidtil er blevet overset i litteraturen og dermed antagelig også i uddannelserne.

\section{Didaktiske overvejelser}

Det er især genoptagelse med de tre hyppigste primærfunktioner rettelse, supplering og opsamling, som danner den egentlige genoptagelsesteknik og kan anbefales som sikkerhedsnet for begyndere. Disse tre er præventive produktionsstrategier, som er nyttige i vanskelige tilfælde, når man vil undgå en overbelastning af hukommelsen. Genoptagelsesteknikken har to store fordele som didaktisk instrument:

- man har en simpel fælles nævner ved løsningen af forskellige typer vanskeligheder og

- man kan styrke de studerendes selvtillid ved at vise, at enhver ytring eller påbegyndt ytring i princippet kan rettes, modificeres og færdiggøres således, at der fremkommer acceptable måltekster også i vanskelige tilfælde.

\section{Litteratur}

Ariel, Mira (1990): Accessing noun-phrase antecedents. London/New York: Routledge.

Beaugrande, Robert-Allan de und Wolfgang U. Dressler (1981): Einführung in die Textlinguistik. Tübingen: Niemeyer.

Chafe, Wallace L. (1982): "Integration and involvement in speaking, writing, and oral literature". I: Tannen, Deborah (ed.): Spoken and written language. Exploring orality and literacy. New Jersey: Ablex, 35-53.

Dubslaff, Friedel (1996): Die Wiederaufnahme durch Proformen beim Simultandolmetschen aus dem Deutschen. Ph.d.-afhandling. Det Erhvervssproglige Fakultet, Handelshøjskolen i Århus.

Gile, Daniel (1995): Basic concepts and models for interpreter and translator training. Amsterdam/Philadelphia: Benjamin.

Halliday, Michael M. K. and Ruquaiya Hasan: Cohesion in English. London/New York: Longman. 
Helbig, Gerhard und Joachim Buscha ( ${ }^{15}$ 1993): Deutsche Grammatik. Ein Handbuch für den Ausländerunterricht. Leipzig/Berlin/München.

Koeppel, Rolf (1993): Satzbezogene Verweisformen. Tübinger Beiträge zur Linguistik 386. Tübingen: Narr.

Lauridsen, Ole og Sven-Olaf Poulsen (1995): Tysk grammatik. København: Munksgaard. 
